\title{
ANTIOXIDANTS, CADMIUM-INDUCED TOXICITY, SERUM BIOCHEMICAL AND THE HISTOLOGICAL ABNORMALITIES OF THE KIDNEY AND TESTES OF THE MALE WISTAR RATS
}

\author{
A. W. OBIANIME AND I. I. ROBERTS+ \\ Departments of Pharmacology and Clinical Pharmacy+, University of Port Harcourt, Nigeria \\ E-mail: tamuno73@yahoo.com Tel: +234 (0) 8037452182
}

\begin{abstract}
Summary: The effects of different doses of cadmium (CD) on some biochemical, hormonal and histopathological parameters of the liver, kidney and testes of the Wister rate were investigated. Cadmium (CD) in the dose range $0-40 \mathrm{mg} / \mathrm{kg}$ while causing a time- and dose-dependent decrease of the basal serum levels of alkaline phosphatese (ALP) also caused a dose-dependent increase in the serum concentration of the acid and prostatic acid phosphatases. The value of the ALP changed from 148.7 $\pm 1.0 \mathrm{IU} / \mathrm{L}$ in the control to $53.7 \pm 0.098$ at $40 \mathrm{mg} / \mathrm{kg}$ of cadmium. While the ACP and ACPT changed from 32.6 \pm 0.72 and $7 \pm$ Units in the control to 54 and 17 units respectively at $40 \mathrm{mg} / \mathrm{kg}$ of CD. Furthermore Cadmium also caused positively correlated dose- and time-dependent destruction of the histology of the liver, kidney and testes. These were characterized by vascular congestion, vacuolation, destruction of the seminal epithelial layers, focal necrosis of nucleus, Oedema of the seminal epithelia layers, focal necrosis of nucleus, oedema of the seminiferous tubules and reduction of spermatogenesis. CD also caused granular and eosinophilic cytoplasm, enlargement of sinusoids with kupffer cells, haemorrhage and apoptosis of cells. Finally pre-treatment with vitamin C $(0.0015 / \mathrm{kg})$, vitamin E $(1.51 / \mathrm{gm})$ and selenium $(0.25 \mathrm{mg})$ which on their own had little or no effects on the serum basal phosphatases, hormonal and histological stability caused a reversal of the cadmium-induced biochemical, hormonal and histological toxicities of the liver, kidney and testes. These results may be explained by the oxidational/antioxidational properties of these xeonobiotics and their mechanisms of actions.
\end{abstract}

Key words: vitamin C, cadmium, kidney, testes, hormones, antioxidants

\section{Introduction}

Cadmium is a transitional metal that exists in different oxidational or transitional states (Donald 1996) it occurs in rock erosion and abrasion and volcanic eruptions Jarup et al 1998; 2000), fossil fuels and particularly non-ferrous mining and metal industries (Friberg et al 1986). The compound has varying degrees of solubility, absorption and toxicity (Falks et al 1990).

Cadmium stimulates and binds to various biological components such as proteins and nonprotein sulfhydryI groups, macromolecules and metallothionein (Klassen 1999). Cadmium has high acute toxicity on developmental effects (Calabrese \& Kenyon 1991). Cadmium toxicity is associated with several clinical complications, renal dysfunction, bone diseases, hepatic dysfunction (Jarup et al. 2000). Renal tubular damage is probably the most common adverse effect (Goyer and Cherian 1995; Jarup et al. 1998). Cadmium toxicity is dependent on dose, duration and route of exposure (Jarup et al. 1998). The liver injury is also of acute toxicity dominated by apoptosis and necrosis, two modes of cell death (Habeebu et al, 1998). Cadmium can also cause various forms of diseases; Osteomalacia and Osteoporosis, Hypertension, Arteriosclerosis, Anaemia and Cancer (Jarup et al 1998; Kjellstrom 1992; Waalkes et al 1999), Cadmium has also been shown to inhibit the activities of various pancreatic proteases (Hideaki et al 1999). Cadmium-induced peroxidation caused the release of free oxygen radicals (Llobert et al 1998). These free radicals cause the stimulation and destruction of sensitive macromolecules and indeed tissues (Lafuente 2000).

Vitamins C, E and selenium are known to be protective anti-oxidants (Stoh et al 2001; Das \& King 2007). They cause the inhibition of peroxidation, mopping up of free oxygen radicals and disorganization and breakage of peroxidation chain reactions (Murray et al 2000) by an inhibition of gluthathione peroxide, Protein Kinase C (PKC) inhibition and calcium metabolism (Stoh et al 2001; Das \& King 2007), thus resulting in the blockade of oxidative mechanisms (Murray et al 2000). However not much is known in these studies of Cadmium about the quantitative and qualitative effects in terms of the dosage, time of action and the type of correlation between biochemical indices and the toxicity to these organs/tissues and their function. Furthermore there is no information on the antagonistic effects of antioxidants on these responses.

It is therefore in this light, that we seek to establish the detailed correlation between biochemical stimulation of these organs using cadmium and their function on one hand, and the effect of anti-oxidants on the other hand. 
A. W. Obianime and I. I. Roberts

Materials and methods

Dose-dependent studies

In five experiments, the effects of intraperitoneal administration of different doses of cadmium chloride on the biochemical, hormonal and histopathological parameters of the male albino rats were investigated. Thirty albino rats of average weight $(400 \pm 5 \mathrm{gms})$ from the animal house of the University of Port Harcourt were divided into six cages of five each. The first was administered with distilled water as control, the second to the sixth cages were administered with different doses of $(0$ $40 \mathrm{mg} / \mathrm{kg}$ ) cadmium chloride. After four hours of administration, the rats were anaethesized, blood and tissue samples were removed and subjected to biochemical, hormonal and histological analysis.

\section{Time-dependenct Studies}

In five experiments, the effects of time of administration on a single dose $(2 \mathrm{mg}$ ) of the cadmium-induced responses of the male albino rats were investigated. Twenty rats, divided into four cages of five rats each were administered with a single dose of cadmium intraperitoneally. The blood and tissue samples were harvested from the first cage on the first day after four (4) hours. The rest were harvested after 24 hours, 4 days and seven days respectively. These were then analysed for biochemical, hormonal and histopathological parameters.

\section{Effects of pre-treatment with anti-oxidants}

In 72 (seventy-two) male albino rats of average weight $400 \pm 5.0 \mathrm{gms}$, the effects of various anti-oxidants (vitamin C $(0.0015 \mathrm{mg} / \mathrm{kg})$ and vitamin $\mathrm{E}(1.5 \mathrm{mg} / \mathrm{kg})$ and co-factor selenium $(2.5 \mathrm{mg})$ were investigated on the cadmium-induced biochemical responses (phosphatase, urea, creatinine), hormonal (Follicle Stimulating Hormone Luteinizing Hormone and Testosterone) and histopathology (liver and testes) of the male rats.

\section{Animals}

All animals used in this study were handled with the international, natural and institutional guidelines for care and use of laboratory animals in biomedical research as promulgated by the Canadian Council of Animal Care (1984). Outbred strains of the female Wistar rats of average weight $250 \mathrm{mg} \pm 6 \mathrm{gms}$ aged between 15-20 weeks were obtained from the animal house of the University of Port Harcourt and allowed to acclimatize for 14 days. They were housed in cages with wire bar lids used to hold the water bottle and feed to prevent contamination with urine or faeces. Bedding was placed directly into the shoe box cage to allow the absorption of urine. They were kept well ventilated room at ambient temperature of $28.0 \pm 2.0^{\circ} \mathrm{C}$ under $12 \mathrm{hr}$ light/dark cycle well fed with food and water ad libitum. Generally the study was conducted in accordance with the recommendations from the declaration of Helsinki on guiding principles in care and use of animals.

\section{Phosphatase Analysis}

Determination of serum alkaline phosphatase (ALP), serum acid phosphatase tartrate and the prostatic phosphatases was carried out using the hydrolysed phenol method (Kind \& King 1954).

\section{Analysis of Urea and Creatinine}

Urea measurements were performed using the diacetyl monoxime a Total urinary excretion method (Toro \& Ackermann 1975), creatinine was assayed using the Jaffe alkaline picrate method (Annino \& Giese 1979).

\section{Hormonal Analysis/Histology}

Blood samples were collected in a $10 \mathrm{ml}$ plastic syringe and kept at room temperature until serum was separated. After centrifugation the serum was transferred to a new tube, kept at room temperature until serum was separated. After centrifugation the serum was transferred to a new tube, kept at $-20^{\circ} \mathrm{C}$ and assayed within 4 weeks. The peptide hormones namely follicle stimulating hormone, luteinizing hormone and prolactin were measured by radioimmunoassay as described by Banu et al (2002). The tissues were isolated and preserved in $10 \%$ formalin routinely processed and stained by the $H \& E$ stain technique for paraffin embedded tissue sections as described by Benjamin (2001). The histopathological tissue sections were photographed with the Leica DMLS camera microscope and analysed.

\section{Statistical Analysis:}

The values were represented as mean \pm SEM at $\mathrm{n}=5$ experiments. The values were taken as significant at $\mathrm{P} \leq 0.05$ ANOVA (analysis of variance).

\section{Results}

The effects of cadmium on the reproductive parameters, phosphatases, hormonal and histopathology of the male Wistar rats were investigated. Also investigated were the effects of anti-oxidants on the cadmium-induced responses.

\section{Serum phosphatases}

Intra-peritoneal administration of different doses of cadmium, caused a dose- and timedependent decrease of the serum alkaline phosphatases changing the control values from $148 \pm 2.42$ to $53.7 \pm 2.1$ at $40 \mathrm{mg} / \mathrm{kg}$ (fig $1 \mathrm{a}$ ). Furthermore, cadmium caused a dose- and timedependent increase of total $\left(\mathrm{AcP}_{\mathrm{T}}\right)$ and prostatic acid phosphatase $\left(\mathrm{AcP}_{\mathrm{P}}\right)$. The control values were changed and increased from 32.6 \pm 0.92 and 
Antioxidants, cadmium toxicity and kidney and testes

$7.0 \pm 0.71$ to $54 \pm 0.77$ and $17.0 \pm 0.48$ for total and prostatic acid respectively (fig $1 \mathrm{~b} \& \mathrm{c}$ ), showing that while cadmium caused a decrease in alkaline phosphatases (ALP), it caused an increase in the value of total $\left(\mathrm{AcP}_{\mathrm{T}}\right)$ and prostatic acid $\left(\mathrm{AcP}_{\mathrm{P}}\right)$. These effects were time-dependent (fig 1c and 2a).

\section{Hormonal effects:}

The administration of different dose of cadmium caused a biphasic dose-dependent increase, followed by a decrease of the male reproductive hormones-follicle stimulating hormone (FSH), luteinizing hormone (LH) and testosterone (fig 2b). These effects were time- and dose-dependent (not shown) on the administration of a single dose. Bolus injection of $2 \mathrm{mg} / \mathrm{kg}$ of cadmium caused a biphasic hormonal response characterized by an immediate spike increase on the first day, followed by a time-dependent decrease which maximizes on the $7^{\text {th }}$ day (fig $2 b$ ) with a value below basal serum concentration.

Histopathological effects on the testes and kidney Administration of cadmium intraperitoneally (IP) caused a dose- and time-dependent destruction of the histology of the testes, liver and kidney of the male Wistar rats.

Testes

In the testes, cadmium in the dose-range (0$40 \mathrm{mg} / \mathrm{kg}$ ), caused a gradual but dose- and timedependent damage to the histology of the testes (figs $3 \mathrm{i}$-vi). These damages were characterized by destruction of germ cells and semniferous tubules, vascular congestion, focal necrosis of tissue, reduction of spermatocytes, pyknosis, destruction of nucleus, oedema in the seminiferous tubules and interstitial tissue (figs 3 i-vi). Furthermore pretreatment with vitamin $\mathrm{C}, \mathrm{E}$ and co-factor selenium which on their on had no deleterious/toxic effects with subsequent administration of cadmium, caused a marked inhibition of the cadmiuminduced destructive responses (figs 3 i-vi). However combined pretreatment with selenium and any of the vitamins (C\&E) with subsequent administration of cadmium, caused a total reversal/antagonism of the cadmium-induced histopathology of the testes (figs 3 i-vi).

\section{Kidney}

Cadmium caused massive local haemorrhage of the renal tissues, while vitamin $\mathrm{E}$ and $\mathrm{C}$ had no effects on the tissues when compared to the control. However combined treatment between vitamin $\mathrm{E}$ and selenium reversed the focal haemorrhage and destruction of the basement membrane of the kidney cells making it look normal (Fig 4).
The effects of pre-treatment with anti-oxidants on biochemical and hormonal parameters

Vitamin C $(0.0015 \mathrm{mg} / \mathrm{kg}), \mathrm{E}(1.5 \mathrm{mg} / \mathrm{kg})$ and selenium $(25 \mathrm{mg})$ which on their own had little or no effects on the basal serum phosphatases, urea, creatinine and hormones on pretreatment with and subsequent administration of $2 \mathrm{mg}$ of cadmium caused an inhibition of the cadmium-induced responses (fig 4a-c). Furthermore a combination of these agents totally blocked the cadmium-induced stimulation of $\mathrm{AcP}_{\mathrm{T}}, \mathrm{AcP}_{\mathrm{T}}$ (fig 4), urea, creatinine (fig 5a and b) and the various hormonal concentrations (fig 6a, b, c and d) showing that the various anti-oxidants reversed the cadmiuminduced biochemical and hormonal responses.

a)

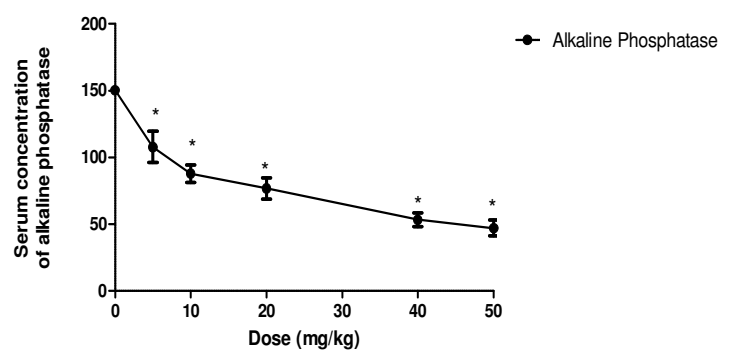

b)
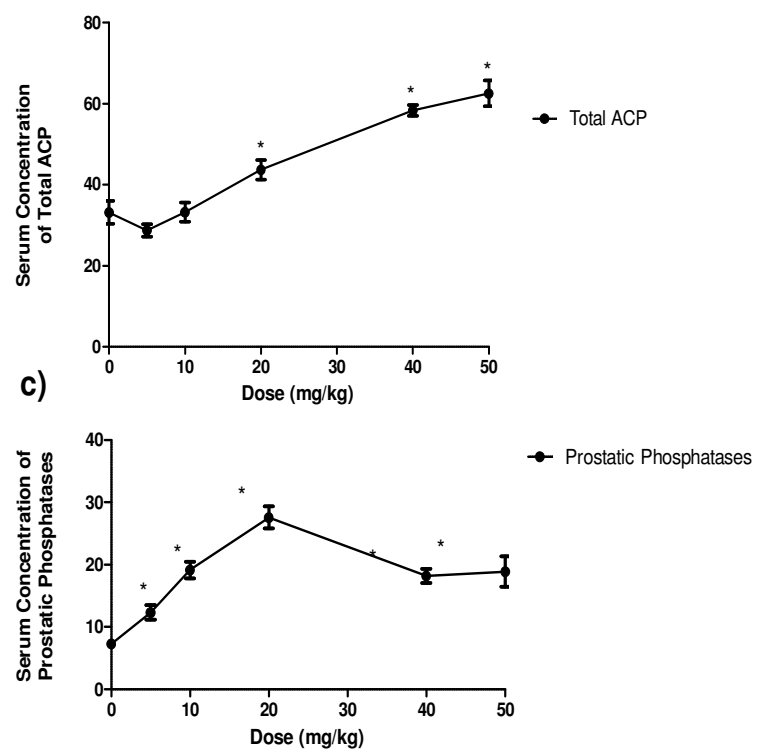

FIG 1. The effects of different doses of cadmium on (a) alkaline phosphatase (b) Total acid phosphatase and (c)prostatic acid phosphatase $n=5$, * significance at $p \leq 0.05$ (ANOVA). 
A. W. Obianime and I. I. Roberts
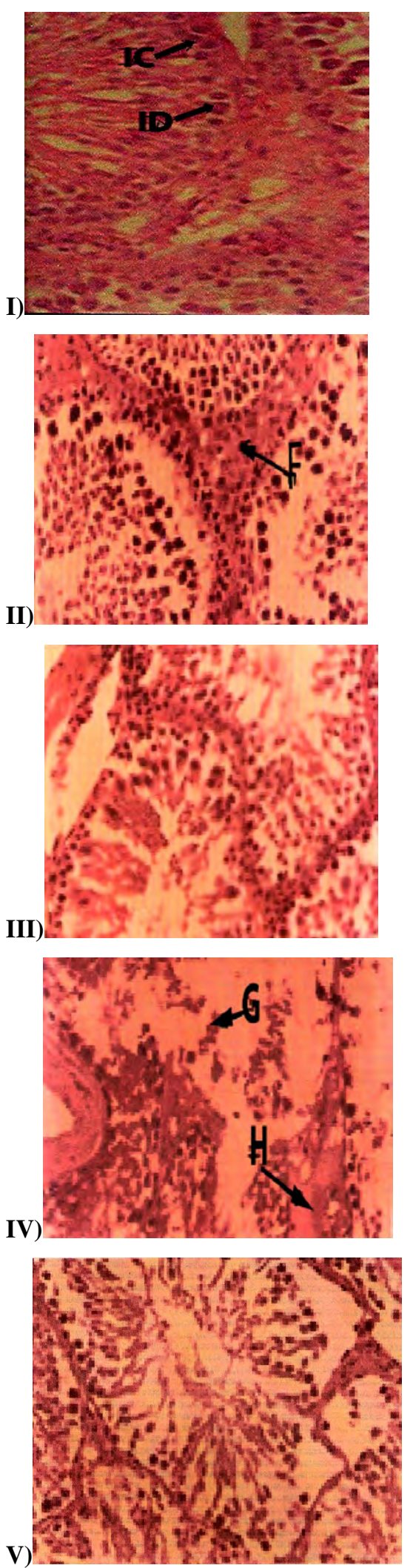

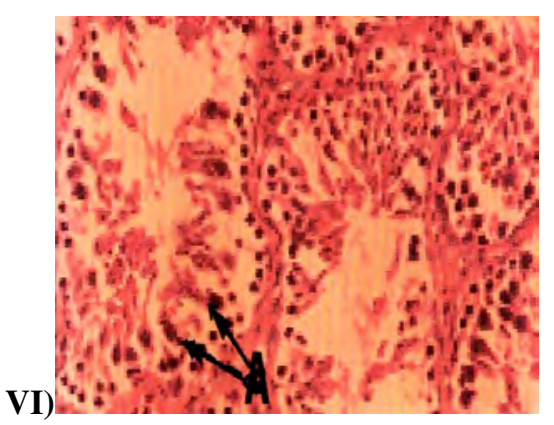

Fig 3. The effects of vitamins $C, E$, Selenium, Cadmium and a combination of cadmium+selenium+vitamin $E$ on the histology of the testis. (I) Control shows the normal testicular architecture (IC) normal germ cell and (ID) normal spermatogonia, (II) Showing the effects of Vitamin C on the testes $(\boldsymbol{F})$ shows an essentially normal but expansion of the interstitial area. (III) Vitamin E tested, (IV) The effects of Cadmium $(C d)$ showing $(\boldsymbol{G})$ nearly complete destruction of the seminiferous tubular contents-germ cells and $(\boldsymbol{H})$ oedematous expansion of the basement membranes of the seminiferous tubules (V) Selenium tested and (VI) Combination of pretreatment with Vitamin $C, E$ \& Selenium on Cadmium showing the normal testicular architecture $(\boldsymbol{A})$.

TABLE: The Effects of Anti-Oxidants on Serum Levels of Urea and Creatinine of the Male Wistar Rats.

\begin{tabular}{|c|c|c|}
\hline Agents & Urea $(i u / l)$ & Creatinine \\
\hline control & $2.10 \pm 0.03$ & $40.0 \pm 2.34$ \\
\hline vitamin $\mathrm{c}$ & $2.11 \pm 0.01$ & $39.4 \pm 3.05$ \\
\hline vitamin e & $1.96 \pm 0.07$ & $39.2 \pm 3.21$ \\
\hline cadmium & $2.91 \pm 0.07 *$ & $55.2 \pm 2.90 *$ \\
\hline selenium & $1.98 \pm 0.03$ & $38.9 \pm 2.98$ \\
\hline vitamin $\mathrm{C}+$ cadmium & $1.81 \pm 0.05^{*}$ & $43.60 \pm 3.46^{*}$ \\
\hline $\begin{array}{l}\text { vitamin } \mathrm{E}+\text { cadmium } \\
\text { vitamin }\end{array}$ & $1.73 \pm 0.02 *$ & $30.90 \pm 3.92 *$ \\
\hline E+cadmium+selenium & $1.21 \pm 0.05^{*}$ & $24.40 \pm 2.2 *$ \\
\hline
\end{tabular}

\section{Discussion}

In this study, cadmium (Cd) was administered through the intraperitoneal (IP) route. This is against the inhalational, oral and dermal routes. However this route of administration, does not in any way affect the results because of (a) repository injection of $\mathrm{Cd}$, such as the IP injection we used, clearly shows release of $\mathrm{Cd}$ from site into systemic circulation (Karprzak and poiriez 1985). This actually increases $\mathrm{Cd}$ systemic values at late times in tissues that accumulate $\mathrm{Cd}$ (Karprzak and poiriez 1985). 
Antioxidants, cadmium toxicity and kidney and testes

a)

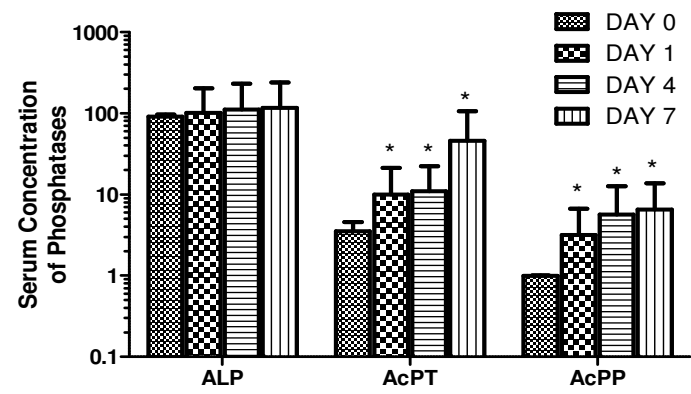

b)

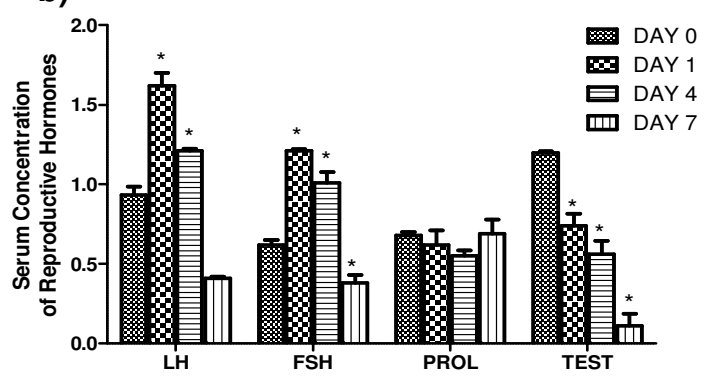

Fig 2 The time-dependent effects of $2 m g$ of cadmium on a) biochemical parameters $\left(A L P, A c P_{T}\right.$ and $\left.A c P_{P}\right)$ and $b$ ) reproductive hormones ( $L H, F S H, P R O L$ and TEST) of the male Wistar rats where $*=$ shows significance at $P \leq$ 0.05 (ANOVA).

TABLE 1: The Effects of antioxidants on alkaline phosphatase, total acid phosphatase and prostatic acid phosphatase

\begin{tabular}{cccc}
\hline Agents & $\begin{array}{c}\text { Alkaline } \\
\text { Phosphatase } \\
(\text { ALP })\end{array}$ & $\begin{array}{c}\text { Total Acid } \\
\text { Phosphatas } \\
e\left(\text { AcP }_{T}\right)\end{array}$ & $\begin{array}{c}\text { Prostatic } \\
\text { Acid } \\
\text { Phosphatas } \\
e\left(\text { AcP }_{T}\right)\end{array}$ \\
\hline Control & $47.3 \pm 2.58$ & $47.3 \pm 3.58$ & $42.3 \pm 2.478$ \\
Vitamin C & $54.2 \pm 3.05$ & $43.4 \pm 3.05$ & $39.56 \pm 2.39$ \\
Vitamin E & $53.1 \pm 3.05$ & $42.7 \pm 2.21$ & $40.21 \pm 4.85$ \\
Cadmium & $51.8 \pm 2.90$ & $79.4 \pm 4.90^{*}$ & $78.2 \pm 2.846^{*}$ \\
$\begin{array}{c}\text { Selenium } \\
\text { Vit. }\end{array}$ & $51.4 \pm 2.98$ & $42.4 \pm 3.98$ & $43.45 \pm 5.78$ \\
C+Cadmium & $64.8 \pm 3.46$ & $61.89 \pm 4.46^{*}$ & $57.97 \pm 2.57^{*}$ \\
Vit. & $58.35 \pm 2.9$ & $47.80 \pm 3.92$ & $42.71 \pm 2.92$ \\
$\begin{array}{c}\text { E+Cadmium } \\
\text { Vitamin E+ }\end{array}$ & & & \\
Cadmium+ & & & \\
Selenium & $59.12 \pm 3.2$ & $33.67 \pm 5.2^{*}$ & $27.40 \pm 3.11^{*}$ \\
\hline
\end{tabular}

$\mathrm{n}=5 *$ shows significance at $\mathrm{P} \leq 0.05$ ANOVA

(b) Cd has a very long biological half life (measured in decades in humans and once deposited is for a longtime irrespective of the route of administration. Thus the precise route of exposure becomes less important compared with other chemical toxicants (Waalkes et al 1999).

In this study, the effects of different doses of cadmium on the serum phosphatases and hormonal concentrations were studied. Also studied were histopathological effects of cadmium on the liver, kidney and the testes. The effects of time on the anti-oxidants on the various parameters were also studied to see if these reactions were easily reversible.

Cadmium is a non-biodegradable metal found in fossils, industry and hydrocarbon industry (Jarup et al 1998, 2000). It is known to cause an effect on serum phosphatase levels by the process of oxidation (Jarup et al 2000). However there have been no known detailed qualitative and quantitative correlative studies done. Neither had there been any correlation studies between the biochemical and pathological effects. In this novel study, we had investigated and tried to correlate the phosphatase levels, with the hormonal and histopathological damages. We had also studied the effects of antioxidants to see if there were any biochemical antagonistic effects to elucidate the mechanism of action of $\mathrm{Cd}$. In this study cadmium caused a dosedependent stimulation or increase of the total acid and prostatic acid levels. This is consistent with the works of (Jarup et al 1998). The increases in activity of acid phosphatases and prostatic phosphatase represent general hepatic toxicity as shown in the liver (Robert et al 1995) and specific toxicity as shown in the prostate gland (Jones et al 1988). Since an increase in phosphatase levels is an index of toxicity (Sukumaran, 1956; Hess, 1975). Histopathological observations also show a doseand time-dependent destruction of the liver, kidney and testes. This is consistent with the earlier works of Habeebu et al 2000; Jones et al 1988 in which they showed that cadmium caused liver, kidney and testicular damage. However what they did not show was the correlation between the increases in phosphatases and histopathological damage. The histopathological damage of the liver also confirms the hepatotoxic levels of cadmium chloride with an increase in urea, creatinine, acid and prostatic acid levels. This is consistent with the earlier works of Goering et al 1994; Habeebu et al 1998; Stoh et al 2000; Massanyi et al 2007; Uche et al 2008). Furthermore, these generalized toxic indices (Friberg 1986) also positively correlated with the damage caused to the testicular tissue. This is also consistent with the earlier works of Jones et al 1988; Massanyi et al 2007 where they showed toxicity but not its correlation. The testes are endocrine organs hence damage to the tissue will result in abnormal endocrine responses. Indeed in this work, because the integrity of the testes was compromised histologically, the serum hormonal levels also fell with time showing a time-dependent pathological destructive response. Furthermore $\mathrm{Cd}$ is known to also directly cause destruction to the testicular organs and hypothalamus-pituitarygonadal axis. 

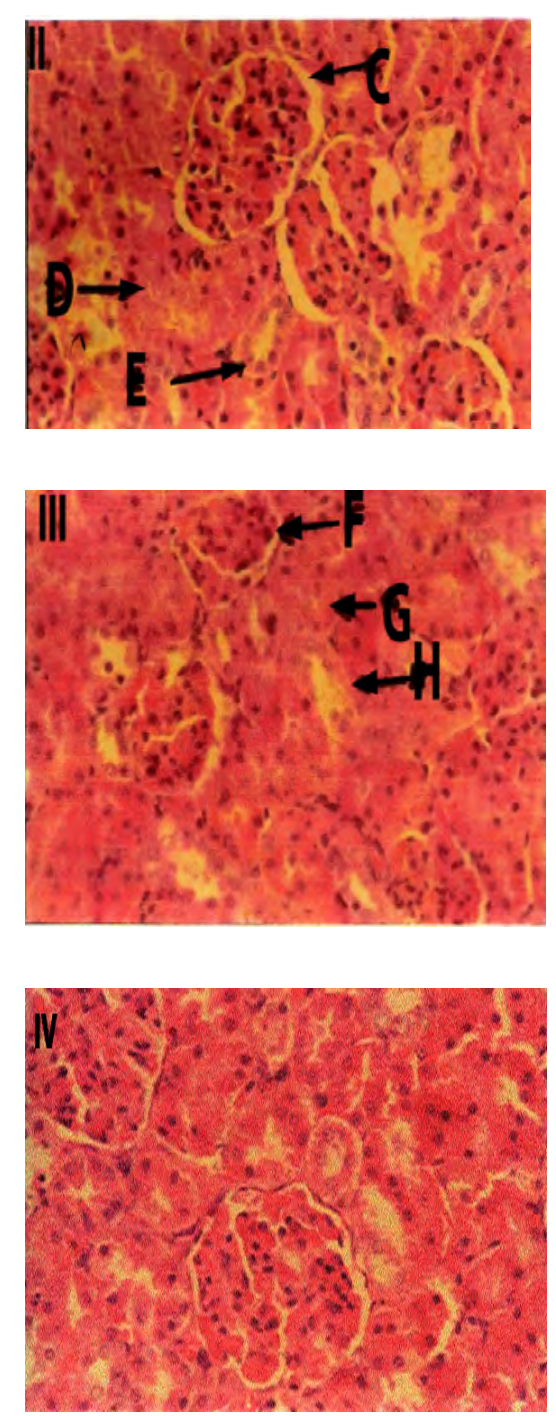

Fig 4. The effect of cadmium and vitamin $E$ and selenium on the histology of the kidneys. Mag $x$ 400. (I) control showing normal glomerulus $(A)$ and normal proximal convoluted tubule (B). (II) Vitamin $C$ treated animals showing normal glomerulus $(C)$, normal proximal convoluted tubule (D) and normal distal convoluted tubule (E). (III) Vitamin E treated animals showing normal glomerulus $(F)$, normal proximal convoluted tubule $(G)$ and normal distal convoluted tubule $(H)$. (IV) Pretreatment with vitamin $E$ and selenium showing normal convoluted tubules and normal glomerulus

Thus destroying the secretory organs of hormones (Massanyi et al 2007) and compromising hormonal release.

Indeed, in this study, cadmium in the dose range studied caused dose- and time-dependent inhibition of the serum hormonal levels of FSH and LH which induce the signals for testosterone synthesis (Cooke et al 1981). An inhibition of these signals results in the time-dependent monophasic serum inhibition in testosterone levels showing reproductive dysfunction, cell death and apoptosis by cadmium (Habeebu et al 1998; Massanyi et al
2007; Stoh et al 2000) resulting in liver and accessory sex tissues atrophy such as the prostate (Waalkes et al 1997a). This will result in reproductive dysfunction.

Similarly other agents like lansoprazole, oxolinic acid and procynidone appear to induce leydig cell damage and tumors of the testis in rats by perturbation of testosterone production and overstimulation of testicular interstitia via increase serum luteinising hormone (Fort et al 1995; Murakani et al 1995; Yamada 1994). This indicates a reduction in normal feedback inhibition mechanism in rats by cadmium at the level of hypothalamus and/or pituitary resulting from reduced testosterone production by the testes which is critical in the formation of testicular interstitial cell tumors. (Waalkes et al 1997b). Furthermore the loss of testosterone feedback can result in pituitary cell hypertrophy, hyperplasia and eventually pituitary neoplasia (Nyska et al 1998). Thus the disruption of the testes-pituitary axis may contribute to the causation of both testicular and pituitary destructions in this study. Exposure of animals to cadmium induced oxidative stress, stimulates the synthesis of cadmium binding proteins metallothioneins (MT) and heat proteins (Klassen et al 1999). Cadmium-induced oxidative stress has been associated with production of reactive oxygen species (ROS) comprising mainly superoxide radical anion $\left(\mathrm{O}_{2}^{-}\right)$, hydrogen peroxide and hydroxyl radical $(\mathrm{OH})$ which lead to lipid peroxidation, membrane protein and DNA damage which can also result in carcinogenesis (Bagchi et al 1996). This had been reported to cause apoptosis, necrosis and cell proliferation (Habeebu et al 2000; Shoh et al 2001). From this study, cadmium stimulated an increase in phosphatase levels (ie acid and prostatic), which resulted and is positively correlated with the histopathological damages. These damages compromised the hormonal endocrine functions of the testes directly and indirectly (Waalkes et al 1999). Anti-oxidants are agents that significantly inhibit the rate of oxidative activity (Murray et al 2000). They can be generally categorized into preventive and nonpreventive antioxidants (Parker 1986). Vitamin C, $\mathrm{E}$ and selenium are the best known preventive antioxidants (Parker 1986). Vitamins C, E and selenium inhibited oxidation by an effect on calcium metabolism, (Stoh et al 2001) protein kinase C (Das and king 2007) inhibition and catalysis of the reduction of hydrogen peroxide which protect biological membranes from oxidative degradation (Murray et al 2000). These agents in combination are known to potentiate synergistically the effects of one another (Heinonen et al 1998; Traber 1999). In this study, vitamin C, E and Selenium, individually and collectively caused an inhibition of cadmium-induced increases or changes in the phosphatase, urea Creatinine and 
Antioxidants, cadmium toxicity and kidney and testes

TABLE 1: The Effects of Anti-Oxidants on the Serum Concentration of Various Hormonal Parameters Follicle Stimulating Hormone, Luteinizing Hormone, Testosterone and Prolactin.

\begin{tabular}{ccccc}
\hline Agents & $\begin{array}{c}\text { Follicle } \\
\text { Stimulating } \\
\text { Hormone }\end{array}$ & $\begin{array}{c}\text { Luteinising } \\
\text { Hormone }\end{array}$ & Testoterone & Prolactin \\
\hline Control & $6.51 \pm 0.34$ & $0.51 \pm 0.012$ & $3.91 \pm 0.045$ & $0.21 \pm 0.0250$ \\
Vitamin C & $5.11 \pm 0.98$ & $0.34 \pm 0.025$ & $3.71 \pm 0.08$ & $0.20 \pm 0.017$ \\
Vitamin E & $5.09 \pm 0.78$ & $5.09 \pm 0.78$ & $3.81 \pm 0.0667$ & $0.20 \pm 0.036$ \\
Cadmium & $5.89 \pm 0.84$ & $5.89 \pm 0.84^{*}$ & $4.983 \pm 1.428^{*}$ & $0.42 \pm 0.32^{*}$ \\
Selenium & $6.23 \pm 0.98$ & $6.23 \pm 0.98$ & $3.95 \pm 0.0478$ & $0.30 \pm 0.025$ \\
Vitamin C+Cadmium & $6.31 \pm 0.846$ & $6.31 \pm 0.846^{*}$ & $3.01 \pm 0.067 *$ & $0.302 \pm 0.025^{*}$ \\
Vitamin E+Cadmium & $6.52 \pm 0.46$ & $6.52 \pm 0.46^{*}$ & $3.45 \pm 0.024^{*}$ & $0.335 \pm 0.038^{*}$ \\
$\quad$ Vitamin E+ & $6.80 \pm 0.97$ & $6.80 \pm 0.97^{*}$ & $5.09 \pm 0.073^{*}$ & $0.257 \pm 0.0023^{*}$ \\
\hline Cadmium/Selenium
\end{tabular}

$\mathrm{n}=5$, significance $*$ at $\mathrm{p} \leq 0.05$.

hormonal parameters thus reversing histological distortions in the liver, kidney and testes of the male Wistar rats. However differences exist in the individual inhibitory activities. Vitamin C, E and Selenium, had no effect on the basal levels: vitamin E caused a gradual inhibition of cadmium-induced responses. A combination of vitamin $\mathrm{C}, \mathrm{E}$ and Selenium totally reversed the cadmium-induced responses. The rank order of the inhibition was the combination (of anti-oxidants) $>$ Vitamin $\mathrm{E}>$ Vitamin C > Selenium. The explanation of this may be in the inhibitory effects of these agents at the transductional levels of cadmium activity (; Das and King 2007; Nishizuka 1986). Stoh et al (2001) hypothesized that in the transductional levels of oxidative trauma of cadmium-induced responses the calcium and protein kinase $\mathrm{C}$ pathways synergized to give the exaggerated responses.

Therefore an inhibition of the calcium pathway of vitamin $\mathrm{C}$ and protein kinase $\mathrm{C}$ pathway by vitamin E (Das and King 2007) coupled with stimulation of the rate of limiting steps by selenium would totally block the transductional events leading to the inhibitory destructive pharmacological responses. This is consistent with the results of this work.

\section{References}

Annino, J.S. Giese, R.W. (1979) Clinical Chemistry, 4th ed. Little Brown, Boston, pp 170-177.

Bagchi, D., Bagchi, M., Hassoun, E., Stohs, S. J. (1996). Cadmium-induced excretion of urinary lipid metabolites, DNA damage, glutathione depletion and hepatic lipid peroxidation in Sprague-Dawley rats. Biol. Trace. Element. Res. 52: 143-154.

Banu, S. K. Govindarajulu, P., Aruldhas, M. M. (2002). Testosterone and estradiol up-regulate androgen and estrogen receptors in immature and adult rat thyroid glands in vivo. Steroids 67: 1007-1014.

Benjamin, M. M. (2001). In: Outline of Veterinary Clinical Pathology. $\quad 3^{\text {rd }}$ ed. Kalyani publishers, New Delhi.

Calabrese, E. J. and Kenyon, E. M. (1991). Air Toxics and Risk Assessment. Lewis Publishers, Chelsea, MI.

Cooke, B. A., Magee-Brown, R., Golding, M. and Dix, C. J. (1981). Heterogeneity of Leydig cells from mouse and rat testes, evidence for a Leydig cell cycle? Int. J. Androl. 4, 355-366.

Das, E. N. and King, G. L. (2007). The role of protein kinase $\mathrm{C}$ activation and the vascular complications of diabetes. Pharmacol Res. 55: 498-510.

Donald, B.C.A., Edward, A. and Ashwood, A.D. (1996). Tiezts- Fundermental Clinical Chemistry. 416. p 145.

Fort, F. L., Miyajima, H., Suzuki, T., Yamamoto, M., Hamashima, T., Sato, S., Kitazaki, T., Mahony, M. C. and Hogden, G. D. (1995). Mechanism for species-specific induction of leydig cell tumors in rat by lansoprazole. Fundam. Appl. Toxicol. 26: 191-202.

Falk, R. T., Pickle, L.W., Fontham, E. T., Correa, P., Morse, A., Chen, V., Fraumeni, J. J. Jr. (1990). Occupation and pancreatic cancer risk in Louisiana. Am. J. Ind. Med., 18: 565-576. 
A. W. Obianime and I. I. Roberts

Friberg, L. Nordberg, G.F. Vouk, V.B. eds. (1986) Handbook of the toxicology of metals. Vol. II. Amsterdam, Elsevier, pp. 130-184.

Goyer, R.A. and Cherian, M.G. (1995). Renal effects of metals. In Metal Toxicology (R. A. Goyer, C. D. Klaassen, and M. P. Waalkes, Eds.), pp 389-412. Academic Press, San Diego.

Goering, P.L. Waalkes, M.P. and Klaassen, C.D. (1994). Toxicology of Cadmium. In Handbook of Experimental Pharmacology; Toxicology of Metals. Biochemical Effects. Vol. 115 (R.A. Goyer and M.G. Cherian, Eds.), pp. 189-214. Springer-verlag, New York.

Habbeebu, S.S. Liu J. and Klaassen, C.D. (1998). Cadmium-induced apoptosis in mouse Liver. Toxicol Appl Pharmacol 149(2):203-209.

Heinonen, O.P. Albanes, O. and Virtamo, J. (1998). prostate cancer and supplementation with alpha-tocopherol and beta-carotene: Incidence and mortality in a controlled trial. J. Natl. Cancer. Just. 90 (6): 440-446.

Hess, B. (1958). DPN-Dependent enzymes in serum. Ann. N.Y. Acad. Sci., 75, 292-303.

Järup, L. Hellström, L. Alfvén, T. Carlsson, M.D. Grubb, A., Persson, B., Pettersson, C., Spang, G. Schutz, A. Elinder, C. (2000). Low level exposure to cadmium and early kidney damage: the OSCAR study. Occup Environ Med 57(10): 668-672.

Järup, L. Berglund, M. Elinder, C.G. Nordberg, G. and Vahter, M. (1998). Health effects of cadmium exposure -a review of the literature and a risk estimate. Scand J Work Environ Health 24(suppl 1):1-51.

Jones, M.M. Cherian, M.G. (1988). The search for chelate antagonists for chronic cadmium intoxication. Toxicology 62:1-25.

Kasprazak, K.S. and Poirier, L.A. (1985). Effects of calcium and magnesium actetates on tissue distribution of carcinogenic doses of cadmium chloride in Wister rats. Toxicology 34, 221230.

Kjellström, T. (1992). Mechanism and epidemiology of bone effects of cadmium. In: Cadmium in the Human Environment: Toxicity and Carcinogenicity, G.F. Nordberg, R.F.M. Herber \& I. Alessio, Lyon eds., International Agency for Research on Cancer Sci. Publ. 118, 301-310.

Klaassen, C.D. Liu, J. and Choudhuri, S. (1999) Metallothionein: an intracellular protein to protect against cadmium toxicity. Аnnu Rev Pharmacol Toxicol 39:267-294.

Lafuente, A., Marquez, N., Perez-Lorenzo, M., Pazo, D. and Esquifino, A. I. (2000). Pubertal and postpubertal cadmium exposure differentially affects the hypothalamic- pituitary-testicular axis function in the rat. Food Chem Toxicol.38: 913-923.

Llobet, J.M. Granero, S. Torres, A. Schuhmacher, M. and Domingo, J.L. (1998b) Biological monitoring of environmental pollution and human exposure to metals in Tarragona, Spain III. Blood levels. Trace Elem Electr 15: 7680.

Kind, P.R.N. and King, E. J. (1954). Estimation of plasma phosphatase by determination of hydrolysed phenol with aminoantipyrine. $J$. Clin. Path. 7: 322-326.

Massanyi, P. Lukac, N. Slivkova, J. Kovacik, J. Makarevich, A.V. Chrenek, P. Toman, R. Forgacs, Z. Somosy, Z. Stawarz, R. Formicki, G. (2007) Mercury-induced alterations in rat kidneys and testes in vivo. J Environ Sci Health A Tox Hazard Subst Environ Eng. Jun;42(7):865-870.

Murray, K.M. Granner, D.K. Mayer, P.A. and Rodwell, V.W. (2000). Harpers Biochemistry $25^{\text {th }}$ Edition 8: 83-85, 130-136.

Murakami, M. Hosokawa, S. Yamada, T. Harakawa, M. Ito, M. koyama, Y. Kimura, J. Yoshitake, A. and Yamada, H. (1995). Species-specific mechanism in rat leydig cell tumorigenesis by procynidone. Toxicol. Appl. Pharmacol. 131. 244-252.

Nishizuka Y. Studies and properties of protein kinase C. Science 1986; 233:305-312.

Nyska, A. Leininger, J.R. Maronpot, R.R. Haseman, J.K. and Hailey, J.R. (1998). Effects of individual versus group caging on the incidence of pituitary and leydig cell tumors in F344 rats: Proposed Mechanism. Med. Hypotheses. 50, 525-529.

Parker, L. (1986). Oxygen radicals and antioxidants in endurance exercise: biochemical aspects of physical exercise. Elsevier Science Publishers Amsterdam.

Roberts, S. A., Nett, T. M., Hartmann, H. A., Adams, J. E. and Stoll, R. E. (1995). SDZ 200-110 Induces Leydig Cell Tumors by Increasing Gonadotrophins in Rats. J. Am. Coll. Toxicol. 8, 487-505.

Stohs, S. J. Bagchi, D., Hassoun, E. and Bagchi, M. (2001). Oxidative mechanisms in the toxicity of chromium and cadmium ions. J. Environ. Pathol. Toxicol. Oncol., 20: 77-88.

Sukumaran, M. and Bloom, W. L. (1953). Influence of diet on serum alkaline phosphatase in rats and man. Proc. Soc. Exp. Biol. and Med. 84: 631-634.

Toro, G. Ackermann, P.G. (1975). Practical clinical chemistry. Little Brown, Boston, pp 148-156.

Traber, M.G. (1999): Vitamin E. In: Shils M., Olson, J.A., Shike, M, Ross, A.C., Eds. Nutrition in Health and Disease ed. $9^{\text {th }}$, 
Antioxidants, cadmium toxicity and kidney and testes

Baltimore: Williams and Wilkins; pp. 347362.

Uche, F.I. Obianime, A.W. Gogo-Abite, M. (2008). Effects of Vanadium Pentoxide on the Histological and Sperm Parameters of Male Guinea Pigs. J. Appl. Sci. Environ. Manage. 12 (3) $107-115$.

Waalkes, M.P. and Rehm, S. Coogan, T.P. and Ward, J.M. (1997a). Role of cadmium in the etiology of cancer of the prostrate. In target organ toxicology series: Endocrine toxicology (J.A. Thomas and H.D. Colby, eds) pp 227244, Raven Press, New York.

Waalkes, M.P. and Rehm, S. and Devor D.E. (1997b). The effects of continuous testosterone exposure on spontaneous and cadmium-induced tumors in the male Fischer (F344/NCr) rat: Loss of testicular response. Toxicol. Appl. Pharmacol. 142: 40-46.
Waalkes, M. P., Anver, M. R., and Diwan, B. A. (1999). Chronic toxic and carcinogenic effects of oral cadmium in the Noble (NBL/Cr) rat: Induction of neoplastic and proliferative lesions of the adrenal, kidney, prostate, and testes. J. Toxicol. Environ. Health 58: 199214.

Yamada, T. Nakamura, J. Murakami, M. Okuno, Y. Hosokawa, S. Matsuo, M. and Yamada, H. (1994). The correlation of serum luteinising hormone levels with induction of Leydig cell tumors in rats by oxolinic acid. Toxicol. Appl. Pharmacol. 129: 146-154.

Received: October 12, 2009

Accepted: December 29, 2009 